\title{
SOCIAL CAPITAL ISSUES IN THE MODERN UZBEK SOCIETY
}

\author{
M. M. Sodirjonov \\ The teacher of Namangan State University, Uzbekistan
}

Article DOI: https://doi.org/10.36713/epra1681

ANNOTATION

This article provides some insights into the stages and ethnic peculiarities of the development of social capital in modern Uzbekistan. It also gives information on the components and factors of development of social capital today.

KEYWORDS: Social capital, socialization, community, trust, ethics, spirituality, talent, ability, solidarity and coherence.

\section{DISCUSSION}

In modern Uzbek society, a new era of focus on education has begun. There is a solid basis for the formation of the national education system, the introduction and use of modern information technologies in all areas, and the expansion of access to world information resources. In the 21 st century, the country's economy, people's lives, and their role in the world community are linked to the development of information technology. It is wellknown that at the rapid pace of development of science and technology, a significant increase in the amount of scientific knowledge, understanding and imagination becomes a significant part of everyday life. This, on the one hand, promotes the differentiation of science and technology through the development of new areas and departments, and on the other hand, the process of integration between disciplines.

The main goal of any society's development is to improve the living standards of the population. The state pursues a strong social policy in order to ensure social stability, economic development, peace and a healthy and prosperous life. With this in mind, from the early stages of the "Strategy for the Further Development of the Republic of Uzbekistan" [1], a lot of creative work was done to ensure the welfare and quality of life of the population. Currently, over $60 \%$ of the State budget is directed to the development of the social sphere.

Enhancing the living standards of the population along with improving the quality of life will contribute to the development of social capital in the country.

Social capital is one of the most widely used concepts in economic literature. Social capital plays an important role in the social development of the state.

In the scientific literature, the term "social capital" was first interpreted by L.J.Khanifan [2.138139] in the form of social relations in small rural communities in 1916. By 1980, French political scientist P.Burhe [3] laid the groundwork for the political and sociological interpretation of the term "social capital". American scholars also investigated the phenomenon of social capital, the sources of formation and development, including political scientist J.Caulman (1990), sociologist A. Portes (1986), and R. Patnem (2000).

Social capital is the result of socialization of people. It creates norms of interpersonal behavior and mechanisms of social interaction.

Social capital in the broadest sense is a combination of material and moral values in society. It is also a reliable form of community in the system of universal human behavior.

In the literature, the definition of "social capital" focuses on ethical behavior, trust and effective co-operation as factors of well-being and development. It is important to note that trust is a common feature of any social capital. Trust is a basic and necessary condition of social capital. Accumulated social capital is also used to determine the role and social status of a person in society. In 


\section{SJIF Impact Factor: 6.260| ISI I.F.Value:1.241| Journal DOI: 10.36713/epra2016 ISSN: 2455-7838(Online) EPRA International Journal of Research and Development (IJRD)}

modern society, the stratification system is not only measured by economic factors, but also by social factors. In particular, German philosopher N. Luman said that trust as a social mechanism governs vague social relations and reduces risk [4.1-3].

F.Fukuyama has introduced the concept of trust-based social capital: "'Trust" is a social event where people meet their needs for a specific purpose and outcome. The role of the family in the formation of social capital and resources is invaluable. "[5.64].

The views of the great thinkers about man and his socialization are also different. In particular, Abu Ali ibn Sina said: "A person becomes a person only because he meets the needs of others, and so do others. One plants, another bakes bread, the third sews clothes, the fourth makes a needle, and all are gathered to meet each other's needs"[6.120].

Abu Nasr Farabi contends that "through wars and violence, people are united into society" and concludes that "society is a voluntary association, first and foremost, meeting the social needs of citizens."

In his work "Ideal people's city", Farabi has scientifically justified the origins of society (the "human community"). The one cannot get these things, he or she needs a team of people to own ... Therefore, it is only through the unification of the many people who are needed to survive, to bring people together, and to help each other that the person can achieve maturity by nature. The activities of such team members will provide each of them with the essentials of survival and maturity. That is why man has multiplied and settled in the inhabited part of the earth, resulting in the human community"[8.18-19].

There are several emerging causes of social capital and several factors:

1. Family - Each family represents a specific social relationship. Accordingly, the impact of the family on the child is specific, and the formation of its moral and moral character is also unique. The role of family in the creation of social capital and resources is invaluable.

2. School is an important stage of sociocultural development.

3. Neighborhood - inheritance factor develops through wedding ceremonies, clean-ups, rituals, ceremonies and traditions.

4. Ethnic groups and relationships - the level of self-awareness of the population, the way of life of citizens, the everyday life style, and the national identity of the nation.

5. Social movements, social institutions, public organizations - programs and actions that promote education, culture, science, literature, arts and sports. It also consists of a system of social and political conditions and effective social networking between public organizations and volunteer associations. As a result, society builds its communications on the basis of specific laws equality, solidarity, openness, mutual respect, trust that are different from the economic and political principles of the country.

With the development of the country, the need for social capital grows and the social welfare of the community increases.

The higher the social capital of this community and the individual is, the more modern scientific and technical development in its place will be, in proportion to the nature, social and interpersonal relationships of the people, the efficiency of production, and the confidence of the leaders and employees.

The following factors should be considered in the development of social capital:

1. The worldview is a social capital, a system of common knowledge about the human being's knowledge, logical thinking, the reality and the attitude of the people around them, as well as the beliefs, ideas, know-how and activities of those people. It is related to the age, life experience, knowledge, and ideology of the person, which is reflected in the philosophical, scientific, religious, political, moral, legal, aesthetic knowledge and views formed in society.

2. Talent is an innate opportunity given to man. It is formed by the combination of reason and thought. The development of social capital becomes a factor of higher efficiency.

3. Research is the pursuit of innovation and the implementation of every innovation. Everyone's aspirations can be seen in the constant improvement of their skills and experience. Initiative is a product of diligence.

4. Contemporary knowledge - a person acquires modern knowledge when he or she obtains the most advanced concepts of his or her life. Contemporary knowledge in social capital is determined by the knowledge of the modern secrets of governance, political awareness, and understanding of secular progress.

5. Patriotism is the patriotism when a common man loves his country. In social capital, a person must not only love his country but also ensure its development.

6. Loyalty to the land is the loyalty of a person to his homeland. Loyalty to the country is reflected in the accumulation of social capital by the implementation of successive programs that determine the future of the country, the well-being and ease of burdens of others.

7. Self-sacrifice is when a person commits self-sacrifice for a noble purpose. The social capital is dedicated to the prosperity of the motherland, peace and prosperity of the people. 
8. Master of his profession is a person who knows the profession of his choice. Professionalism in social capital means the formation of modern knowledge and skills, along with knowledge of the latest achievements of their profession.

9. Belief in faith is the belief that a person will adhere to what he believes. In social capital, however, it is faith-based, with a strong will, that addresses today's and tomorrow's problems, solving problems of the time.

The following concepts are important for the development of social capital:

Firstly, mutual trust is important for each person in the socio-economic relationship, based on the factor of mutual trust, to develop our national customs and ideas, such as the kindness and honor that lies at the heart of it.

Secondly, social cohesion - social cohesion in social capital can be predicted as follows: social solidarity, inter-ethnic harmony, interfaith tolerance, and interethnic tolerance.

Thirdly, social cohesion is an important component of social capital. In human history and in the experience of developed countries ("Japanese character", "Korean nature"), this factor is justified. Ensuring social cohesion is the achievement of social tensions and inequalities to the extent that entire groups and segments of the population feel unfairly overlooked or discriminated against.

Fourthly, social justice covers all areas of social life. In civil society, when one sees the principles of justice in his personal life and in the community, he can only be convinced that he is a humane social system. However, in this social process, the principles of social justice also require that human rights and human rights be fully respected.

The long historical processes of each society develop on the basis of social partnerships and traditions of people. Development is also reflected in such factors as mutual trust, social values, voluntary participation in government and non-government organizations, activity and initiative. In order to do so, various factors that contribute to human relations and build trust in contemporary Uzbek society are transforming social capital into a particular potential and integral part of society through individual and collective cooperation, dialogue and shared relationships.

In the development of social capital of the country, democratization of all spheres of social life, changes in the socio-political and economic spheres play an important role. This, in turn, is the basic criterion for meeting the social needs of a person, social protection, non-infringement of individual rights, building a democratic and legal state, and, in general, respecting human dignity and values.

It is necessary to implement the principles of social justice in the social life, first and foremost, to carry out the tasks of socio-economic and cultural importance on the basis of the established social capital. It requires a conscious creative approach to labor, an assessment of its effectiveness and quality, and compliance with the law of self-management in the labor process. If all of the above is introduced into public life, then one will have to fulfill civil duties in society.

\section{REFERENCES}

1. Ўзбекистон Республикаси Президентининг Фармони. Ўзбекистон Республикасини янада ривож-лантириш буйчча Харакатлар стратегияси тугрисида. $\check{У}_{3}$ Қонун хужжатлари туиплами, 2017 й., 6-сон, 70модда.

2. Hanifan L.J. The Rural School Community Centr, annaks of the American Academy of Political and social Sciences, 67, 1916. Pp. 130-138.

3. Bourdie P. The forms of capital // Handbook of theory and research for sociology of Edication. Ed. by J. Richardson. New York: Greenword Press, 1986

4. Luhmann N. Trust and Power. Willy, 1979. P.1-3.

5. Фукуяма Ф. Доверие: сочиальнқе добредетели и путь $\kappa$ процветанию: пер. с. Анг. / Ф. Фукуяма. - M, 2008 С. 64.

6. Рахимов С.Р. Психолого-педагогические взглядқ Абу Али ибн Сино. - Т.: Ўқ̧итувчи, 1979. C.120

7. Форобий Абу Наср. Фозил одамлар шахри. Тошкент: А.Қодирий ном. Халқ мероси наириёти. 1993. 